\title{
HUBUNGAN PANJANG-BERAT DAN NISBAH KELAMIN LOBSTER BATU (Panulirus penicillatus) DI PANTAI SELATAN YOGYAKARTA
}

\author{
LENGTH-WEIGHT RELATIONSHIP AND SEX RATIO OF DOUBLE-SPINED ROCK \\ LOBSTER (Panulirus penicillatus) IN THE SOUTHERN COAST OF YOGYAKARTA
}

\author{
Rakhma Fitria Larasati ${ }^{*}$, Eko Setyobudi ${ }^{2}$, Suadi $^{2}$ \\ ${ }^{1}$ Politeknik Kelautan dan Perikanan Jembrana, Desa Pengambengan, Jembrana, Bali 82218 \\ ${ }^{2}$ Departemen Perikanan, Fakultas Pertanian, Universitas Gadjah Mada, Jalan Flora, Gedung A-4, \\ Bulaksumur, Sleman, Yogyakarta 55281
}

Teregistrasi I tanggal: 25 Februari 2021; Diterima setelah perbaikan tanggal: 26 Mei 2021; Disetujui terbit tanggal: 31 Mei 2021

\begin{abstract}
ABSTRAK
Lobster (Panulirus spp.) adalah komoditas perikanan penting dan ekonomis tinggi. Spesies yang paling sering dan dominan tertangkap adalah lobster batu. Meningkatnya permintaan lobster menjadikan nelayan melakukan kegiatan penangkapan secara terus menerus. Penelitian ini bertujuan untuk menganalisis hubungan panjang-berat dan rasio jenis kelamin (sex ratio) lobster batu (Panulirus penicillatus). Penelitian dilakukan pada Februari 2017 sampai dengan Agustus 2017 di pantai selatan Yogyakarta. Kajian stok lobster dilakukan melalui survei yang meliputi metode deskriptif, observasi dan wawancara. Pemilihan lokasi pengambilan sampel dilakukan secara terpilih (purposive) yaitu pantai Ngrenehan, Baron, Drini dan Tepus. Total sampel lobster batu yang diperoleh sepanjang penelitian sejumlah 546 ekor, yang terdiri dari lobster jantan 289 ekor (53\%) dan lobster betina 257 ekor (47\%). Hasil penelitian menyatakan bahwa pola hubungan panjang dan berat lobster batu memiliki sifat allometrik negative dengan persamaan $\mathrm{W}=0,004 \mathrm{~L}$ 2,577 pada lobster jantan dan $\mathrm{W}=0,007 \mathrm{CL}^{2,481}$ pada lobster betina. Perbandingan nisbah kelamin lobster batu jantan dan betina adalah 1,12: 1 .
\end{abstract}

Kata kunci: Panjang-berat, nisbah kelamin, Panulirus penicillatus, Yogyakarta

\begin{abstract}
Lobster (Panulirus spp.) is an important and economically high fishery commodity. The most frequent and dominant species caught is rock lobster. The increasing demand for lobsters makes fishermen conduct continuous catching activities. The study aims to analyze the relationship of length-weight and sex ratio of rock lobster (Panulirus penicillatus). The research was conducted from February 2017 to August 2017 in southern coast of Yogyakarta. The study of lobster stocks was conducted through surveys that included descriptive methods, observations and interviews. The sampling location was chosen purposively, namely Ngrenehan, Baron, Drini and Tepus. Total samples obtained throughout the study amounted to 546 double-spined rock lobster, consisting of 289 males (53\%) and 257 females (47\%). The results stated that the length and weight relationship pattern of rock lobsters is negative allometric, with the equation $W=0,004 L^{2,577}$ in males lobster and $W=0,007 C L^{2,481}$ in females lobster. The sex ratio double-spined rock lobster between males and females lobster is $1,12: 1$.
\end{abstract}

Keywords: length-weight, sex ratio, Panulirus penicillatus, Yogyakarta

Korespondensi penulis:
*Email: rakhmafitrialarasati@gmail.com

DOI: http://dx.doi.org/10.15578/plgc.v2i2.9809 


\section{PENDAHULUAN}

Lobster (Panulirus spp.) sering disebut udang barong adalah suatu komoditas perikanan penting dan memiliki nilai ekonomi yang tinggi (Mahdiana \& Laurensia, 2010). Tingginya nilai ekonomi lobster dapat dijadikan sebagai sumber devisa negara (Pratiwi, 2008). Asia, Eropa dan Amerika merupakan wilayah yang menduduki tingkat permintaan pasar yang sangat besar (Witomo \& Nurlaili, 2015). Penambahan permintaan lobster pada umumnya diiringi dengan peningkatan harga. Meningkatnya harga lobster juga dipengaruhi oleh terbatasnya volume produksi (Boesono et al., 2011). Penentuan harga lobster pada umumnya dikategorikan berdasarkan ukuran, jenis dan musim penangkapan. Beberapa kelebihan lobster yaitu memiliki nilai gizi dan protein penunjang konsumsi yang tinggi (Pratiwi, 2008).

Produksi lobster sampai saat ini masih dihasilkan dari usaha penangkapan (Kusuma et al., 2012). Lobster merupakan target tangkapan nelayan dengan menggunakan krendet (Bakhtiar et al., 2013). Krendet adalah alat tangkap yang bersifat pasif dan termasuk dalam alat perangkap (trap). Spesies yang paling sering dan dominan tertangkap adalah lobster batu (Panulirus penicillatus) (Wirosaputro, 1996; Mahasin, 2003; Fauzi et al., 2013). Meningkatnya permintaan lobster menjadikan nelayan melakukan kegiatan penangkapan secara terus menerus. Usaha penangkapan yang semakin intensif dan kurangnya kesadaran akan kelestarian sumberdaya ikan telah menimbulkan terjadinya tekanan sumberdaya yang semakin berat sehingga dikhawatirkan akan mengarah pada overfishing (Kementerian Kelautan dan Perikanan, 2012). Minimnya penanganan intensitas penangkapan juga membawa dampak pada ukuran rata-rata lobster yang semakin kecil (Bakhtiar et al., 2013).

Daerah Istimewa Yogyakarta mempunyai garis pantai sepanjang 113 $\mathrm{km}$ dengan sektor perikanan tangkap yang cukup tinggi. Daerah yang berpotensi dan dapat dikembangkan adalah Kabupaten Gunungkidul (Wahyuningrum et al., 2012). Potensi yang menjadi unggulan adalah spesies lobster yang terdapat di berbagai titik pantai selatan Yogyakarta. Kajian tentang hubungan panjang dan berat adalah hal yang berarti bagi suatu penelitian perikanan, karena kondisi ini dapat menyampaikan informasi mengenai parameter populasi. Pertama, perubahan panjang dan berat akan memperlihatkan umur dan kelas kelompok tahun ikan; kedua, data panjang dan berat bisa dipakai untuk menjelaskan kemampuan stok perikanan tangkap. Cara untuk memastikan seimbang atau tidaknya antara panjang dan berat lobster dapat dilihat dari hasil perhitungan nilai $b$. Pengukuran panjang dan berat lobster menurut Richter (2007) dapat digunakan sebagai pedoman mengenai kondisi ikan, antara lain: tingkat kegemukan, tingkat kesehatan, produktivitas dan kondisikondisi fisiologis dari ikan misalnya perkembangan gonad.

Lobster merupakan spesies target dari alat tangkap krendet yang berada di pantai selatan Gunungkidul sebelum tahun 1980an (Suadi, 2002). Alat tangkap yang dioperasikan tidak hanya krendet tetapi juga jaring insang (gillnet monofilament). Alat tangkap jaring insang dapat digunakan untuk menangkap lobster seperti halnya di Pangandaran (Nawangwulan, 2001) dan Kebumen (Saputra, 2009). Total pendapatan nelayan di pantai selatan Yogyakarta cukup relevan karena adanya peran serta dari penghasilan usaha perikanan tangkap. Namun mulai tahun 1997 hingga tahun 2000 terjadi penurunan produksi perikanan lobster dan 
ukuran hasil tangkapan semakin mengecil (Suadi, 2002).

Dalam rangka mendukung upaya pengelolaan lobster yang berkelanjutan, diperlukan suatu kajian informasi dasar biologi perikanan lobster untuk mengetahui pola pertumbuhan. Hubungan panjang dan berat dapat mengetahui pola pertumbuhan lobster hasil tangkapan. Tujuan dilakukannya perhitungan panjang dan berat lobster adalah untuk melihat konversi dan skala panjang ke berat atau berat ke panjang, maka bisa dijadikan informasi bagi kegemukan, produktifitas, kesehatan, dan kondisi fisiologis serta perkembangan gonad (Merta, 1993). Pemanfaatan sumberdaya lobster harus dikelola secara berkelanjutan, yang berarti pemanfaatannya tidak boleh melebihi potensi lestari yang ada. Berdasarkan hal tersebut, maka tujuan penelitian ini adalah untuk mengetahui hubungan panjang-berat dan nisbah kelamin (sex ratio) lobster batu (Panulirus penicillatus) di pantai selatan Yogyakarta. Hasil penelitian bisa dijadikan masukan untuk menentukan kebijakan pengelolaan sumberdaya lobster di pantai selatan Yogyakarta secara berkelanjutan.

\section{BAHAN DAN METODE}

\section{Lokasi dan Waktu Penelitian}

Objek yang diamati selama penelitian adalah lobster batu yang tertangkap oleh nelayan di pantai selatan Yogyakarta dan didaratkan dibeberapa titik pendaratan serta pengepul lobster di daerah Ngrenehan, Baron, Drini dan Tepus (Kabupaten Gunungkidul) (Gambar 1). Penelitian dilakukan pada Februari sampai dengan Agustus 2017. Kajian stok lobster dilakukan melalui survei yang meliputi metode deskriptif, observasi dan wawancara.

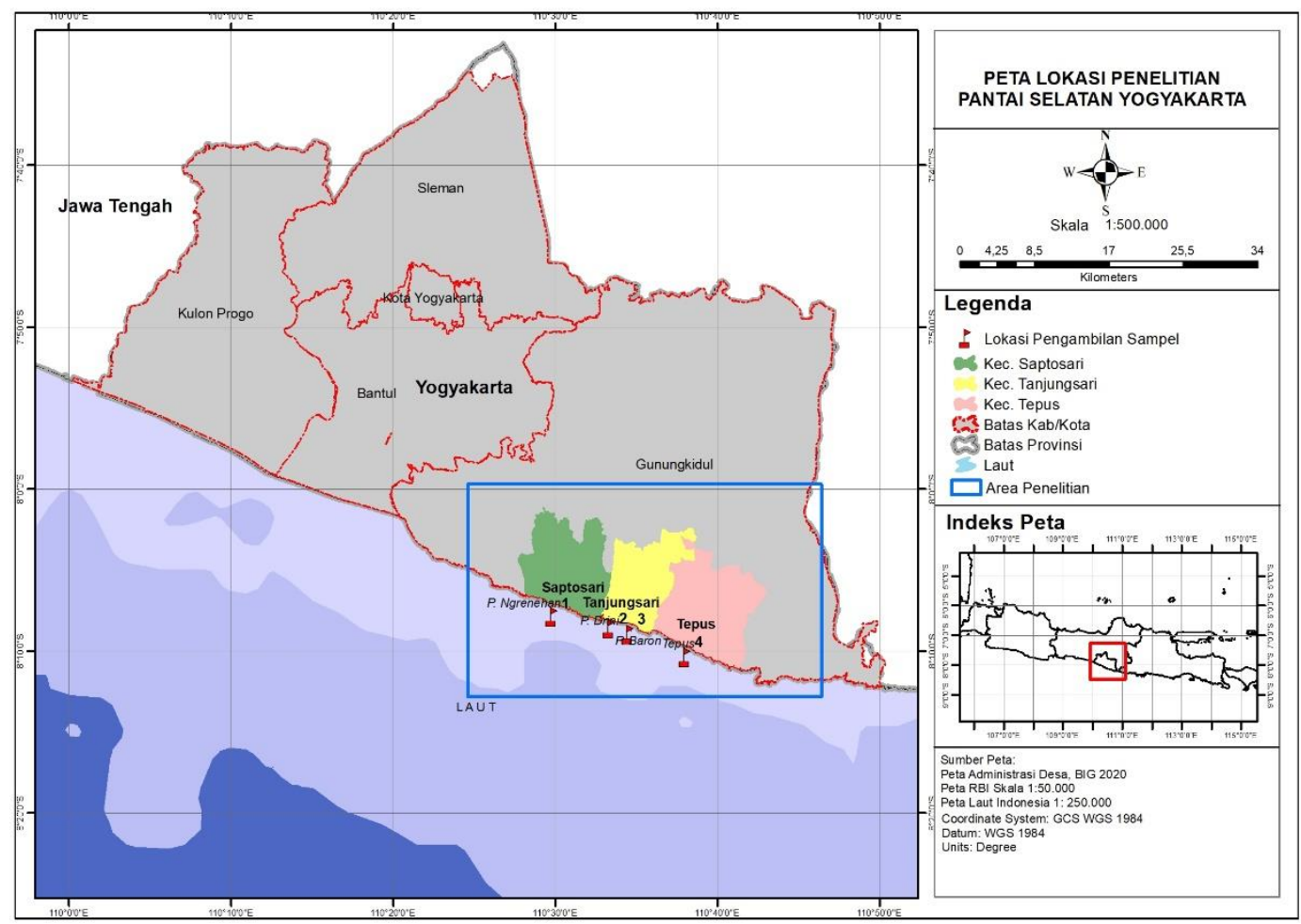

Gambar 1. Lokasi stasiun sampling lobster batu di pantai selatan Yogyakarta

Figure 1. The location of sampling double-spined rock lobster station in the southern coast of Yogyakarta 
Data yang digunakan meliputi data aspek biologi dan aspek reproduksi lobster batu ( $P$. penicillatus). Parameter biologi lobster yang dijadikan pengamatan, antara lain panjang karapas (mm) dan berat individu (g). Kemudian untuk aspek reproduksi meliputi nisbah kelamin. Pengambilan data biologi didapat melalui pengukuran lobster yang didaratkan di tempat pendaratan ikan dan juga di pengepul setempat. Metode yang digunakan untuk pemilihan nelayan yang dijadikan sampel pengukuran lobster menggunakan purposive sampling, sedangkan pengukuran panjang dan berat lobster dilakukan secara sensus terhadap beberapa spesies lobster yang terperangkap oleh para nelayan yang lokasinya sudah terpilih sebelumnya. Berdasarkan Mossa \& Aswandy (1984), identifikasi lobster dapat dilihat secara visual melalui pengamatan pola warna yang berada pada segmen tubuh.

Menurut Sparre \& Venema (1999), ukuran yang paling akurat untuk lobster adalah panjang karapas. Pengukuran panjang karapas lobster diawali dengan mengukur mulai dari tepi post orbital (belakang mata) sampai dengan ujung posterior karapas (batas terakhir karapas dengan abdomen).

Lobster yang menjadi sampel diukur panjang karapasnya dengan memakai jangka sorong digital dengan akurasi $0,1 \mathrm{~mm}$ dan dilakukan penimbangan beratnya dengan memakai timbangan digital akurasi 0,1 g (Gambar 2). Penentuan jenis kelamin lobster dapat dilakukan dengan pengamatan visual.
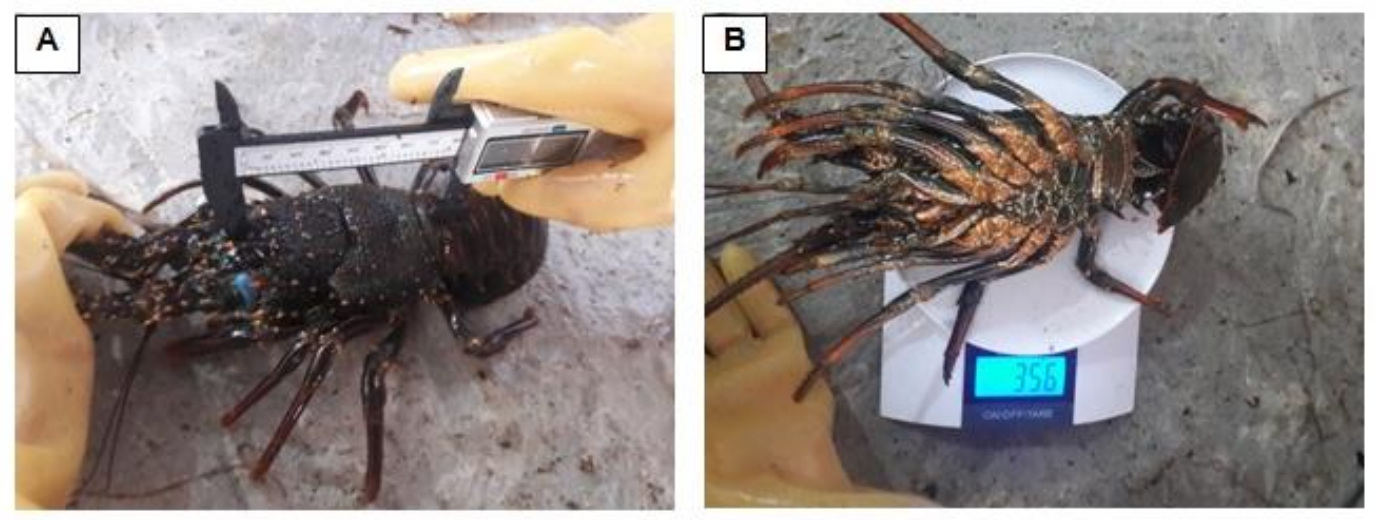

Gambar 2. Pengukuran panjang karapas dan berat lobster batu

Figure 2. Measuring carapace length and weight of double-spined rock lobster

\section{Analisis data}

Hubungan panjang-berat

Analisis hubungan panjang dan berat lobster memiliki tujuan untuk mengetahui pola pertumbuhan lobster di alam. Hubungan panjang dan berat dapat diestimasi berlandaskan model kubik pada persamaan eskponensial (Sparre \& Venema, 1999), dengan rumus sesuai Pers. (1).

$$
\mathrm{W}=\mathrm{a} C L^{\mathrm{b}}
$$

Keterangan:

$$
\begin{aligned}
\mathrm{W}= & \text { berat lobster }(\mathrm{g}) \\
\mathrm{CL}= & \text { panjang karapas }(\mathrm{mm}) \\
\mathrm{a}= & \text { eksponen intercept } \text { (perpotongan } \\
& \text { antara garis regresi } \mathrm{y}) \\
\mathrm{b}= & \text { tangen sudut kemiringan (slope) }
\end{aligned}
$$

Uji-t (uji parsial) digunakan untuk memastikan nilai $b=3$ atau $b \neq 3$ dengan hipotesis:

- Apabila nilai $b=3$, maka pola pertumbuhan lobster bersifat isometrik (pertambahan panjang tubuh lobster seimbang dengan pertambahan beratnya). 
- Apabila nilai $b \neq 3$ maka pertumbuhan lobster bersifat allometrik, yaitu:

a. b>3 disebut pola pertumbuhan allometrik positif (pertumbuhan berat lebih dominan, bentuk lobster cenderung gemuk)

b. $\mathrm{b}<3$ disebut pola pertumbuhan allometrik negatif (pertumbuhan panjang lebih dominan, bentuk lobster cenderung kurus).

\section{Nisbah kelamin}

Nisbah kelamin dipergunakan untuk memprediksi perbandingan lobster jantan dan betina yang berada pada suatu perairan. Perhitungan nisbah kelamin lobster dilakukan melalui persamaan Pers. (2) berikut (Effendie, 2002).

$$
N K=\frac{\mathrm{Nb}}{\mathrm{Nj}} .
$$

\section{Keterangan:}

$\mathrm{NK}=$ nisbah kelamin

$\mathrm{Nb}=$ jumlah lobster betina (ekor)

$\mathrm{Nj}=$ jumlah lobster jantan (ekor)

Langkah selanjutnya dilakukan pengujian antara rasio jumlah lobster jantan dan betina dengan memakai $U j i$ chi-square $\left(x^{2}\right)$ pada selang kepercayaan 95\% $(\mathrm{p}=0,05)$, bertujuan untuk menilai keseragaman. Perhitungan Uji-chi square ( $\left.x^{2}\right)$ diperoleh berdasarkan Pers. (3) (Hedianto \& Purnamaningtyas, 2013).

$$
\chi^{2}=\Sigma \frac{(f 0-f h)^{2}}{f h}
$$

\section{Keterangan :}

$$
\begin{aligned}
& \chi^{2}: \text { Chi-Square } \\
& \mathrm{f}_{0}: \text { frekuensi lobster jantan dan } \text { betina yang diamati } \\
& \mathrm{f}_{\mathrm{h}}: \text { frekuensi lobster jantan dan } \\
& \\
& \text { betina yang diharapkan }
\end{aligned}
$$

Nilai $x^{2}$ diperoleh dari perhitungan diatas, kemudian nilainya dibandingkan dengan nilai $x^{2}$ tabel menggunakan taraf kepercayaan $95 \%$, derajat bebas $(\mathrm{db})=1$ (satu) memakai hipotesis:

$$
\begin{aligned}
& \chi^{2}{ }_{\text {hitung }}<\chi^{2} \text { tabel }(0,05) \text { terima } \mathrm{H}_{0}, \\
& \text { berarti tidak terdapat } \\
& \text { perbedaan yang nyata untuk } \\
& \text { nisbah kelamin jantan dan } \\
& \text { betina. } \\
& \chi^{2} \text { hitung }>\chi^{2} \text { tabel }(0,05) \text { terima } \mathrm{H}_{1}, \\
& \text { berarti terdapat perbedaan } \\
& \text { yang nyata untuk nisbah } \\
& \text { jantan dan betina. }
\end{aligned}
$$

\section{HASIL DAN BAHASAN \\ HASIL \\ Hubungan panjang dan berat}

Total sampel lobster batu yang diperoleh semasa penelitian adalah 546 ekor, yang meliputi lobster jantan 289 ekor (53\%) dan lobster betina 257 ekor (47\%). Berdasarkan total sampel, panjang karapas lobster batu berkisar antara 35,2$120,5 \mathrm{~mm}$ dengan rerata $\pm 63,5 \mathrm{~mm}$. Pada lobster batu jantan berkisar antara 35,2$120,5 \mathrm{~mm}$ dengan rata-rata $64,20 \mathrm{~mm}$ dan lobster batu betina berkisar antara 35,6$90,6 \mathrm{~mm}$ dengan rata-rata $62,83 \mathrm{~mm}$ (Gambar 3 dan Gambar 4).

Berdasarkan hasil sebaran ukuran panjang karapas lobster tidak ditemukan ukuran panjang karapas $<35 \mathrm{~mm}$ atau $>125 \mathrm{~mm}$. Atas dasar Peraturan Menteri No. 12 Tahun 2020 bahwa 80\% lobster batu yang tertangkap dibawah ukuran panjang karapas $8 \mathrm{~cm}$.

Sifat pertumbuhan lobster dapat diketahui melalui hubungan panjang dan berat. Perolehan nilai b pada lobster batu jantan sebesar 2,577 dan 2,481 pada lobster batu betina. Setelah memperoleh nilai $b$, maka didapatkan hasil persamaan hubungan panjang dan berat lobster batu jantan $\mathrm{W}=0,004 \mathrm{CL}^{2,577}$ dan persamaan lobster batu betina $\mathrm{W}=0,007 \mathrm{CL}^{2,481}$ (Gambar 5 dan Gambar 6). Perhitungan uji t diperoleh hasil $b<3$, bisa disimpulkan masuk pada kategori allometrik negatif, mempunyai arti bahwa pertumbuhan panjang lebih cepat daripada berat, sehingga bentuk lobster cenderung kurus. 
Hubungan Panjang-Berat ...... Pantai Selatan Yogyakarta (Larasati, et al)

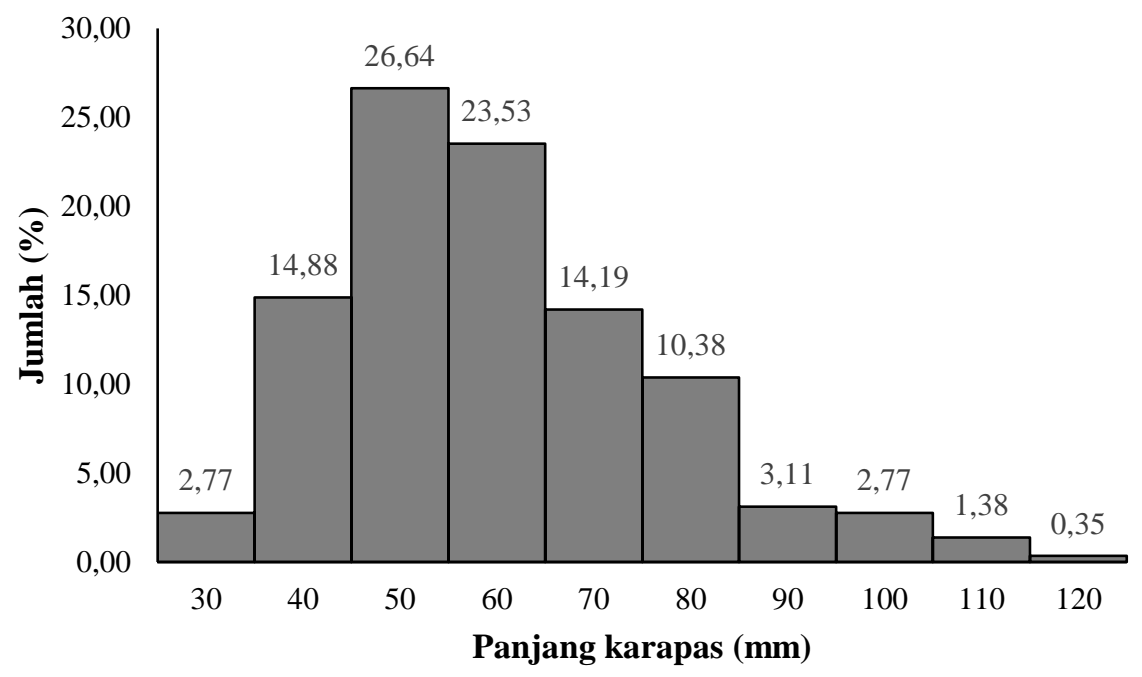

Gambar 3. Distribusi frekuensi panjang karapas lobster batu (P. penicillatus) jantan Figure 3. Distribution of carapace length of males double-spined rock lobster (P. penicillatus)

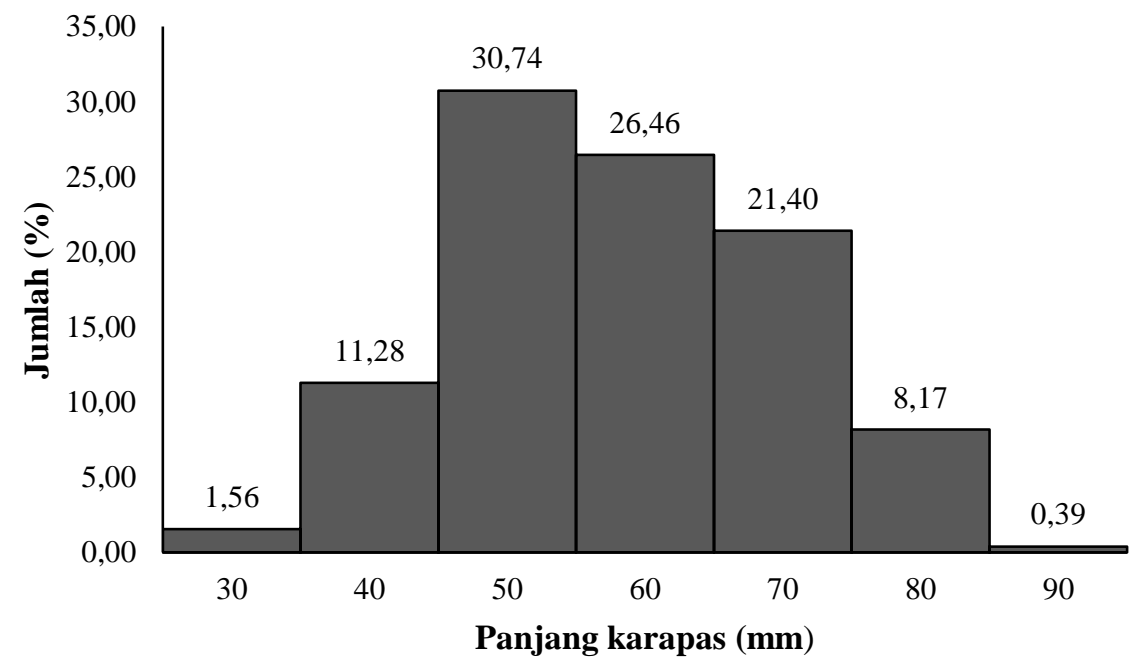

Gambar 4. Distribusi frekuensi panjang karapas lobster batu (P. penicillatus) betina Figure 4. Distribution of carapace length of females double-spined rock lobster (P. penicillatus)

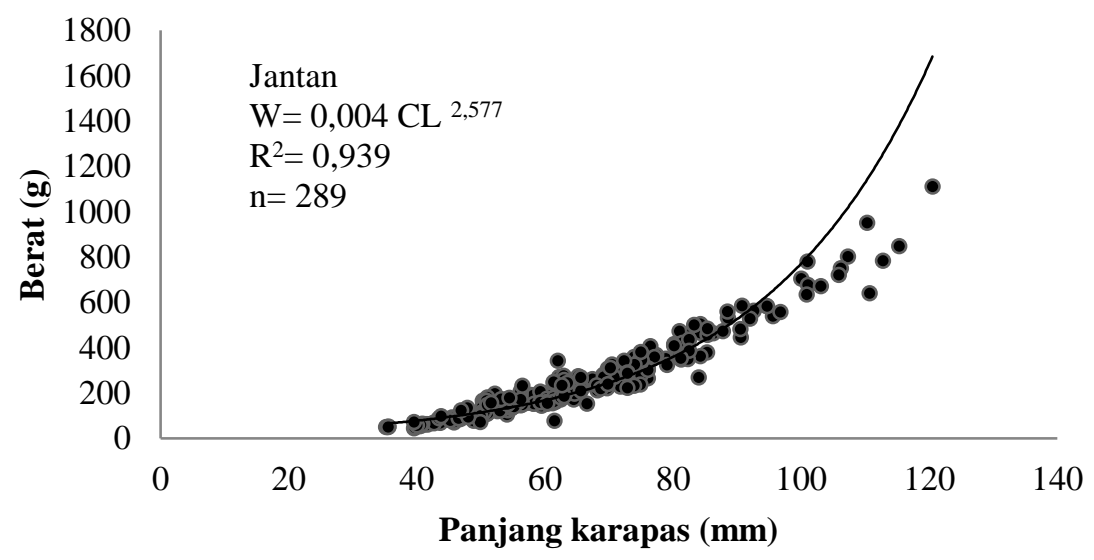

Gambar 5. Grafik hubungan panjang-berat lobster batu jantan Figure 5. Length-weight relationship of males double-spined rock lobster 
PELAGICUS: Jurnal IPTEK Terapan Perikanan dan Kelautan

Volume 2 Nomor 2: 83-93, Mei 2021

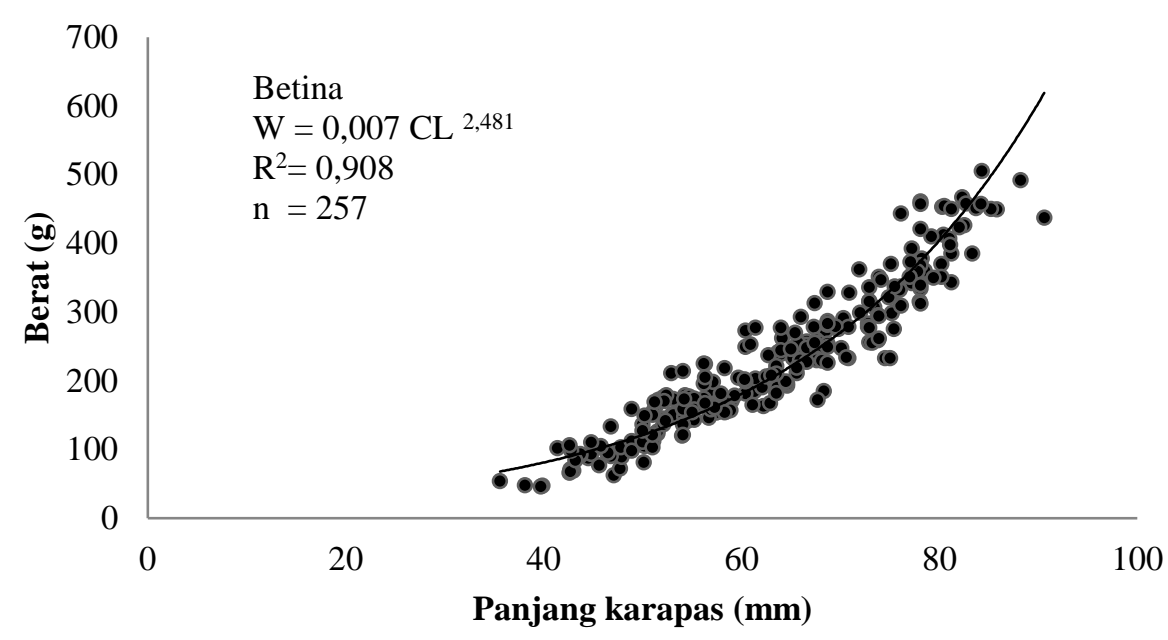

Gambar 6. Grafik hubungan panjang-berat lobster batu betina

Figure 6. Length-weight relationship of females double-spined rock lobster

\section{Nisbah kelamin}

Perbedaan jenis kelamin lobster batu dapat dilihat dari beberapa ciri morfologi eksternalnya. Perbedaan jenis kelamin lobster dapat diketahui dari posisi alat kelaminnya, pada lobster jantan terdapat di antara kaki jalan (pereopod) ke lima, tajam, dan menonjol keluar, serta terdapat kaki renang (pleopod) selembar berbentuk daun. Sementara pada lobster betina, ujung ruas kaki jalan kelima memiliki cabang tiga dan kaki renang terdapat lembaran berpasangan (Gambar 7).
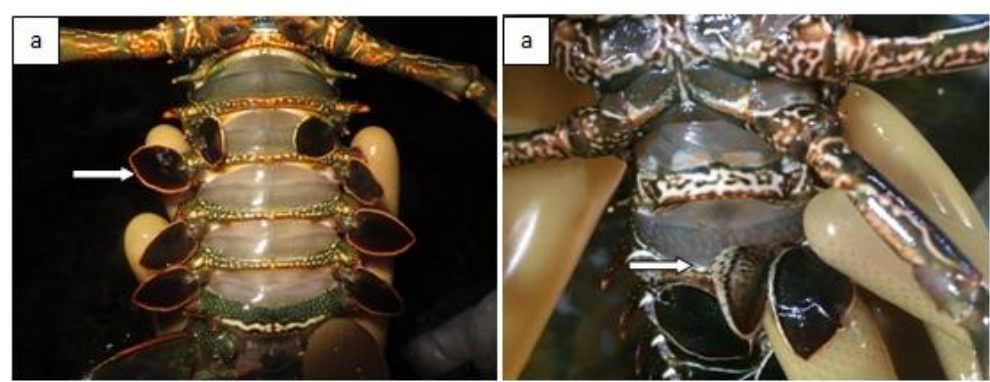

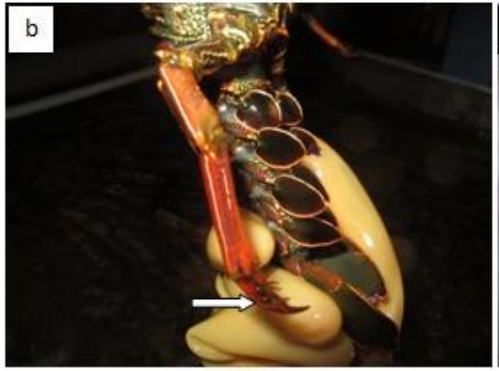

1.Jantan

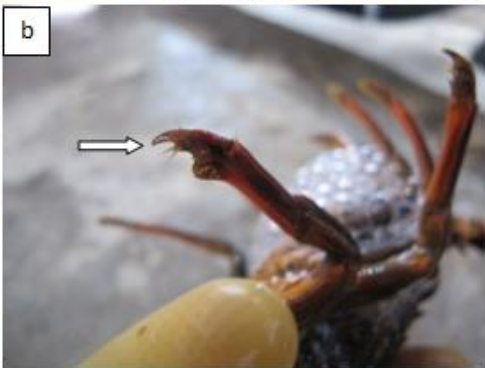

2. Betina

Gambar 7. Ciri perbedaan jenis kelamin, a. Pleopod; b. Ujung kaki jalan kelima

Figure 7. Characteristics of sex differences $a$. Pleopod; $b$. The fifth leg 
Hasil penelitian menunjukkan bahwa perbandingan sampel lobster batu jantan lebih besar daripada sampel lobster batu betina $(52,93 \%):(47,07 \%)$ (Gambar 8). Perbandingan antara lobster jantan dengan lobster betina yaitu $1,12: 1$.

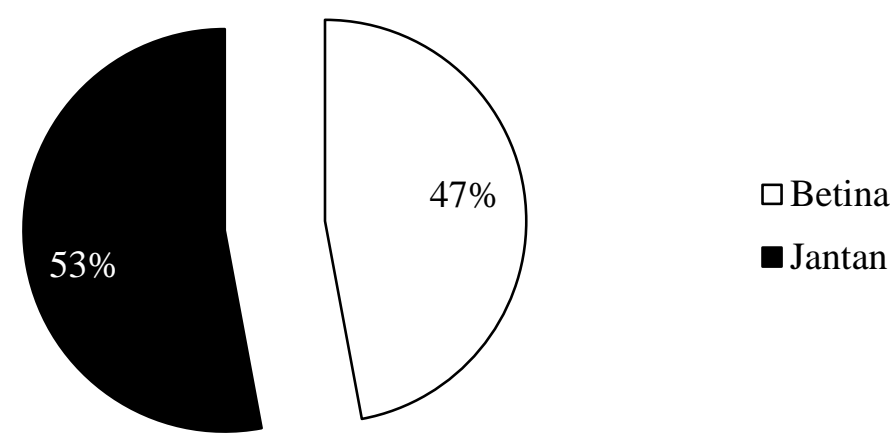

Gambar 8. Rasio antara lobster batu jantan dan betina

Figure 8. The ratio between males and females lobster

Keakuratan perhitungan perbandingan jenis kelamin lobster ditunjukkan oleh hasil uji Chi-Kuadrat $\left(x^{2}\right)$ (Tabel 1) dengan nilai sebesar 1,87, yang berarti $\left(x^{2}\right.$ hitung $<x^{2}$ tabel $)$ bahwa tidak ada selisih yang nyata antara total lobster batu jantan dan total lobster batu betina.

Tabel 1. Hasil perhitungan analisis pada lobster batu

Table 1. T-test result for double-spined rock lobster

\begin{tabular}{lllllllc}
\hline Sampel & $\mathrm{f}_{0}$ & $\mathrm{f}_{\mathrm{h}}$ & $\mathrm{f}_{0}-\mathrm{f}_{\mathrm{h}}$ & $\left(\mathrm{f}_{0}-\mathrm{f}_{\mathrm{h}}\right)^{2}$ & $\left(\mathrm{f}_{0}-\mathrm{f}_{\mathrm{h}}\right)^{2} / \mathrm{f}_{\mathrm{h}}$ & $\sum\left(\mathrm{f}_{0}-\mathrm{f}_{\mathrm{h}}\right)^{2} / \mathrm{f}_{\mathrm{h}}$ & $\chi_{\text {tabel }}^{2}$ \\
\hline Jantan & 289 & 273 & 16 & 256 & 0,9377 & \multirow{2}{*}{1,87} & 3,84 \\
\hline Betina & 257 & 273 & -16 & 256 & 0,9377 & & \\
\hline
\end{tabular}

$\mathrm{f}_{0}=$ frekuensi yang diamati (observasi)

$\mathrm{f}_{\mathrm{h}}=$ frekuensi yang diharapkan

\section{BAHASAN}

Perolehan dari hasil penelitian menunjukkan pola pertumbuhan lobster batu di pantai selatan Yogyakarta memiliki sifat allometrik negatif. Hasil penelitian Hargiyatno et al. (2013) di perairan Yogyakarta dan Pacitan juga memperoleh sifat allometrik negatif dengan persamaan lobster batu $\mathrm{W}=$ $0,002 \mathrm{CL}^{2,754}$ pada jantan dan $\mathrm{W}=$ $0,002 \mathrm{CL}^{2,828}$ pada betina. Demikian pula hasil penelitian di perairan selatan Gunungkidul dan Pacitan (jantan W=
$0,002 \mathrm{CL}^{2,755}$, betina $\mathrm{W}=0,001 \mathrm{CL}^{2,882}$ ) (Fauzi et al., 2013), dan di perairan Wonogiri, Jawa Tengah (jantan $\mathrm{W}=0,003 \mathrm{CL}^{2,680}$, betina $\mathrm{W}=0,004 \mathrm{CL}^{2,590}$ ) (Zaenuddin \& Putri., 2017). Perbandingan hasil riset di atas digunakan untuk memonitoring data pertumbuhan panjang karapas lobster pada tahun yang berbeda. Pengukuran panjang dan berat lobster menurut Richter (2007), ditujukan untuk mendapatkan data variasi panjang dan berat lobster secara individu atau kelompok individu, yang dapat 
digunakan untuk pedoman terkait kondisi lobster. Kesesuaian pola pertumbuhan ditilik dari kecocokan karakteristik perairan untuk mendukung ketersediaan makanan dan habitat yang sesuai (Fauzi $e t$ al., 2013).

Model pertumbuhan bersifat allometrik negatif menunjukkan bahwa perkembangan panjang lobster batu lebih cepat dari perkembangan berat lobster batu. Berdasarkan hasil uji-t pada tingkat kepercayaan $95 \%$ dari nilai b terhadap nilai 3 untuk kedua jenis kelamin lobster batu, didapatkan $t_{\text {hitung }}(10,90)>t_{\text {tabel }}$ $(1,96)$ untuk lobster jantan dan $t_{\text {hitung }}$ $(10,53)>t_{\text {tabel }}(1,96)$ untuk lobster betina yang berarti memiliki hasil yang signifikan (berbeda nyata). Berdasarkan taraf korelasi (r) pada lobster jantan dan lobster betina memperoleh hasil mendekati satu menandakan terdapatnya hubungan yang erat antara pertambahan panjang dan beratnya.

Model pertumbuhan didapatkan melalui nilai $b$ pada persamaan hubungan panjang dan berat lobster. Terdapat nilai b dari hasil penelitian Hargiyatno et al., 2013; Fauzi et al., 2013; Zaenuddin \& Putri, 2017 yang mengindikasikan perbedaan nilai meskipun mempunyai pola pertumbuhan yang sama. Nilai $b$ yang berbeda mengindikasikan hubungan panjang dan berat yang cenderung dikarenakan aspek biologis dan ekologis (Manik, 2009). Aspek biologis terdiri dari jenis kelamin, fase pertumbuhan, perkembangan gonad, dan kebiasaan makan (Froese, 2006; Tarkan et al., 2006). Aspek ekologis yang mempengaruhi yaitu kualitas air, musim, $\mathrm{pH}$, suhu, salinitas dan posisi geografis (Jenning et al., 2001). Pola hubungan panjang dan berat akan membias dari hukum kubik apabila keadaan lingkungan yang beralih sehingga bisa menyebabkan keadaan ikan berubah (Merta, 1993).

Hasil penelitian nisbah kelamin beberapa spesies lobster telah banyak dilakukan dan memperlihatkan hasil yang beragam antar wilayah. Hasil penelitian
Wirosaputro (1996) di Gunungkidul mengemukakan bahwa nisbah kelamin $P$. penicillatus antara jantan : betina adalah 1,83: 1. Kembaren \& Nurdin (2015) dari penelitiannya di Aceh Barat menunjukkan bahwa nisbah kelamin $P$. homarus adalah $1: 1,05$ dan di perairan Pelabuhan Ratu 1 : 1,05 (Islamiati, 2017). Ernawati et al. (2014) pada $P$. versicolor di Kabupaten Sikka juga mengemukakan bahwa nisbah kelamin antara jantan : betina yaitu 1,09: 1, sedangkan di Ambon pada penelitian Ongkers et al. (2014) memperoleh hasil $1: 0,81$.

Kanciruk (1980) menyatakan bahwa nisbah kelamin lobster tingkatan post larva dan juvenile muda pada perairan dangkal antara jantan : betina adalah 1 : 1. Rasio lobster jantan dan betina yang sebanding menunjukan bahwa lobster jantan dan betina mempunyai kesempatan terjerat secara bersamaan. Perbandingan lobster jantan maupun betina diharapkan ada pada keadaan seimbang, paling tidak lobster betina lebih melimpah sekalipun rasio kelamin di alam kerap timbul penyimpangan dari keadaan ideal (Ball \& Rao, 1984). Berdasarkan hasil penelitian menginfomasikan bahwa nisbah kelamin belum mencukupi kriteria yang diharapkan dalam menjaga kondisi sumberdaya agar tetap stabil, karena dari hasil sampling lobster jantan lebih dominan yang tertangkap daripada lobster betina. Ketidakseimbangan ini bisa dipengaruhi oleh beberapa faktor, meliputi makanan, populasi dan keseimbangan rantai makanan. Menurut Effendie (2002), perbedaan nisbah kelamin juga bisa timbul karena faktor lain yaitu perbedaan pola tingkah laku lobster jantan dan betina, aspek penangkapan dan kondisi lingkungan. Perbedaan kelamin bisa berubah-ubah menjelang dan semasa periode pemijahan terjadi. Populasi ikan jantan akan lebih dominan tertangkap dari pada betina, hal tersebut terjadi pada waktu melangsungkan proses ruaya pemijahan 
(Nikolsky, 1963 dalam Setyohadi \& Wiadnya, 2018).

\section{SIMPULAN}

Bersumber pada hasil analisis diatas dapat diperoleh kesimpulan:

1. Panjang karapas lobster batu berkisar antara 35,2-120,5 $\mathrm{mm}$ dengan rerata \pm 63,5 mm. Ukuran minimum panjang karapas yang boleh ditangkap sesuai Peraturan Menteri No. 12 Tahun 2020 sebesar $8 \mathrm{~cm}$.

2. Lobster batu di pantai selatan Yogyakarta memiliki pola pertumbuhan allometrik negatif, yang menunjukkan pertambahan panjang lobster lebih cepat daripada pertambahan beratnya.

3. Nisbah kelamin lobster batu jantan : betina yaitu $1,12: 1$.

\section{DAFTAR PUSTAKA}

Bakhtiar, N. M., Solichin, A. \& Saputra, S. W. (2013). Pertumbuhan dan laju mortalitas lobster batu (Panulirus homarus) di Perairan Cilacap Jawa Tengah. Diponegoro Journal of Maquares, 2, 1-10.

Boesono, H., Anggoro, S. \& Bambang, A. N. (2011). Laju tangkap dan analisis usaha penangkapan lobster (Panulirus sp.) dengan jaring lobster (Gillnet monofilament) di Perairan Kabupaten Kebumen. J. Saintek Perikanan, 7, 77-87.

Effendie, M. I. (2002). Biologi Perikanan. Yogyakarta: Yayasan Pustaka Nusantara.

Ernawati, T., Kembaren, D. D., Suprapto, \& Sumiono, B. (2014). Parameter populasi lobster bambu (Panulirus versicolor) di Perairan Utara Kabupaten Sikka dan sekitarnya. $J$. Bawal, 6 (3), 169-175.

Fauzi, M., Prasetyo, A. P., Hargiyatno, I. T., Satria, F. \& Utama, A. A. (2013). Hubungan panjang-berat dan faktor kondisi lobster batu
(Panulirus penicillatus) di Perairan Selatan Gunungkidul dan Pacitan. J. Bawal, 5 (2), 97-102.

Froese, R. (2006). Cube law, condition factor and weight-length relationships: history, metaanalysis and recommendations. Journal of Applied Ichthyology, 22, 241-253.

Hargiyatno, I. T., Satria, F., Prasetyo, A. P. \& Fauzi, M. (2013). Hubungan panjang - berat dan faktor kondisi lobster pasir (Panulirus homarus) di Perairan Yogyakarta dan Pacitan. J. Bawal, 5(1), 41-48.

Hedianto, D.A. \& Purnamaningtyas, S.E. Biologi reproduksi ikan golsom (Hemichromis elongatus, Guichenot 1861) di Waduk Cirata, Jawa Barat. J. Bawal, 5 (3), 159166.

Islamiati, N. (2017). Dinamika Populasi Lobster Pasir (Panulirus homarus) di Perairan Pelabuhanratu, Kabupaten Sukabumi Jawa Barat. Skripsi. Institut Pertanian Bogor. Bogor.

Jennings, S., Kaiser, M. J. \& Reynolds, J. D. (2001). Marine Fishery Ecology (p. 417). Oxford-US: Blackwell Sciences.

Kanciruk P. (1980). Ecology of juvenile and adult Palinuridae (Spiny Lobsters) dalam Cobb and Phillips (1980). The Biology and Management of Lobsters. Ac. Press: 1, 70-71.

Kembaren, D. D. \& Nurdin, E. (2015). Distribusi ukuran dan parameter populasi lobster pasir (Panulirus homarus) di Perairan Aceh Barat. $J$. Bawal. 7(3), 121-128.

Kusuma, R. D., Asriyanto \& Sardiyatmo. (2012). Pengaruh kedalaman dan umpan berbeda terhadap hasil tangkapan lobster (Panulirus spp.) dengan jaring lobster (bottom gill net monofilament) di Perairan Argopeni Kabupaten Kebumen. Journal of Fisheries Resources 
Utilization Management and Technology, 1, 11-21.

Mahasin, M. Z. (2003). Kajian Stok dan Bioekonomi Lobster (Panulirus spp.) untuk Menunjang Pemanfaatan Berkelanjutan di Provinsi Daerah Istimewa Yogyakarta. Tesis. Universitas Diponegoro. Semarang.

Mahdiana, A. \& Laurensia. (2010). Status perikanan lobster (Panulirus spp.) di Perairan Kabupaten Cilacap. Sains Akuatik, 13 (2), 52-57.

Manik, N. (2009). Hubungan panjangberat dan faktor kondisi ikan layang (Decapterus russelli) di perairan sekitar Teluk Likupang, Sulawesi Utara. Oseanologi dan Limnologi Indonesia, 35 (1), 65-74.

Merta, I. G. S. (1993). Hubungan panjang-berat dan faktor kondisi ikan lemuru, Sardinella lemuru Bleeker, 1853 dari perairan Selatan Bali. J. Pen Per Laut. 73, 35-44.

Moosa, M.K. \& Aswandy, I. (1984). Udang Karang (Panulirus spp.) dari Perairan Indonesia. Jakarta: Lembaga Ilmu Pengetahuan Indonesia.

Nawangwulan, S. (2001). Analisis Sistem Penangkapan Lobster (Panulirus sp.) di Perairan Pangandaran Kabupaten Ciamis Jawa Barat. Skripsi. Institut Pertanian Bogor. Bogor.

Ongkers, O. T. S., Pattiasina, B. J., Tetelepta, J. M. S., Natan, Y. \& Pattikawa, J. A. (2014). Some biological aspects of painted spiny lobster (Panulirus versicolor) in Latuhalat waters, Ambon Island, Indonesia. AACL Bioflux, 7(6), 469474.

Pratiwi, R. (2008). Aspek biologi udang ekonomis penting. Oseana, 33 (2), 15-24.

Richter, T.J. (2007). Development and evaluation of standard weight equations for bridgelip sucker and largescale sucker. Nort American Journal of Fisheries Management, 27, 936-939.

Saputra, S. W. (2007). Buku ajar mata kuliah dinamika populasi. Universitas Diponegoro. Semarang. Setyohadi, D. \& Wiadnya, D. G. R. (2018) Pengkajian Stok dan Dinamika Populasi Ikan Lemuru. Malang: UB Press.

Sparre, P. \& Venema, S. C. (1999). Introduksi Pengkajian Stok Ikan Tropis (p.438), Buku 1: Manual. Jakarta: Pusat Penelitian dan Pengembangan Perikanan.

Suadi. (2002). Dari petani menjadi nelayan: Kajian historis perikanan tangkap Pantai Selatan Yogyakarta. J. Perikanan UGM, 4 (1), 5-12.

Tarkan, A. S., Gaygusuz, O., Acipinar, P., Gursoy, C. \& Ozulug, M. (2006). Length-weight relationship of fishes from the Maxmara region (NW-Turkey). Journal of Applied Ichthyology, 22, 271-273.

Wahyuningrum, P. I., Nurani, T. W. \& Rahmi, T. A. (2012). Usaha perikanan tangkap multi purpose di Sadeng, Kabupaten Gunungkidul, Daerah Istimewa Yogyakarta. Maspari Journal, 4 (1), 10-22.

Wirosaputro, S. (1996). Jenis dan seks rasio udang barong (Panulirus spp.) di Kawasan Pantai Gunungkidul, Yogyakarta. J. Perikanan UGM, 1 (1), 12-21.

Witomo, C. M. \& Nurlaili. (2015). Strategi keberlanjutan pengelolaan bibit lobster di Perairan Lombok. $J$. Kebijakan Sosek KP, 5 (1), 11-18.

Zaenuddin, M \& Putri, D. A. D. (2017). Sebaran ukuran lobster batu (Panulirus penicillatus) di Perairan Wonogiri Jawa Tengah. Saintek Perikanan, 12 (2), 109-115. 